\title{
Incidence, morbidity, mortality, and prevalence of diabetes in Denmark, 2000-20 I I: results from the Diabetes Impact Study 2013 [Corrigendum]
}

Green A, Sortsø C, Jensen PB, Emneus M. Clin Epidemiol.

2015;7:421-430.

On page 426, Figure 2, the y-axis label should have been "Standardized incidence rate (per 10,000 person-years)".

On page 426, Figure 2, the title should have been "Figure 2 Standardized incidence rate of diabetes, 2000-2011, (per 10,000 person-years)".

On page 426, left column, line 9, the citation for Table 1 should have been a citation for "Table 2 ".

\section{Publish your work in this journal}

Clinical Epidemiology is an international, peer-reviewed, open access, online journal focusing on disease and drug epidemiology, identification of risk factors and screening procedures to develop optimal preventative initiatives and programs. Specific topics include: diagnosis, prognosis, treatment, screening, prevention, risk factor modification, systematic reviews, risk \& safety of medical interventions, epidemiology \& biostatistical methods, and evaluation of guidelines, translational medicine, health policies \& economic evaluations. The manuscript management system is completely online and includes a very quick and fair peer-review system, which is all easy to use. submit your manuscript | www.dovepress.com

Dovepress

http://dx.doi.org/10.2147/CLEP.S101648 